\title{
Mass-balance estimates for Haut Glacier d'Arolla, Switzerland, from 2000 to 2006 using DEMs and distributed mass-balance modeling
}

\author{
Ruzica DADIC, ${ }^{1}$ Javier G. CORRIPIO, ${ }^{1,2}$ Paolo BURLANDO ${ }^{1}$ \\ ${ }^{1}$ Institute of Environmental Engineering, ETH Zürich, CH-8093 Zürich, Switzerland \\ E-mail: dadic@ifu.baug.ethz.ch \\ ${ }^{2}$ Tropical Glaciology Group, Department of Earth and Atmospheric Sciences, University of Innsbruck, \\ Innrain 52, A-6020 Innsbruck, Austria
}

\begin{abstract}
A distributed mass-balance modeling approach is required to assess the impact of future climate scenarios on water availability in glaciated basins. Accurate estimation of water stored within the snow, firn and ice of such basins requires knowledge of the distributed snow and ice mass balance throughout the year. In this study, we estimate the annual mass balance and runoff for Haut Glacier $d^{\prime}$ Arolla, Switzerland, from 2000 to 2006. Our estimations are based on observed elevation changes from three digital elevation models (DEMs) derived from aerial photographs in September 1999 and 2005, and October 2006. In addition to these estimations, we implement a combined field observation and a distributed mass-balance modeling approach. An energy-balance model driven by meteorological variables from automatic weather stations inside the catchment area, including gravitational snow transport, is run for the period 2005-06. The model results are validated with direct snow water equivalent measurements as well as with runoff measurements. Combining the mass-balance measurements, energy-balance calculations and measured runoff, we estimate the contribution from ice melt to the runoff for this period to be $25-30 \%$, the contribution from snowmelt $50-60 \%$ and the contribution from rain $15-25 \%$. Our model results also show that the snow distribution affects both snow and ice melt. It is therefore important for water resources management to understand the distribution of snow in alpine catchments, as it seems to be the controlling factor for the timing of streamflow throughout the year as well as for the total availability of water.
\end{abstract}

\section{INTRODUCTION}

In the European Alps and most other areas of the world the retreat of glaciers is a widely observed fact. The most important climate-change effect on water availability is a change in the timing of streamflow throughout the year (Arnell, 1999), considering that a major proportion of annual streamflow is formed by snowmelt in spring. Furthermore, valley glaciers represent a storage of water. The impact of glacier retreat on water resources is due not only to a smaller storage in the form of ice with increasing melt, but also to the overall decrease in altitude in a catchment. The decrease in altitude leads to higher temperatures and enhances the decrease in the snow to rain ratio. This has implications for the timing of the streamflow, with a shift from spring snowmelt to summer runoff (Arnell, 1999). Ice melt is therefore expected to be enhanced due to earlier snow depletion.

In this paper, ice volume loss has been estimated using DEMs from different time periods. The estimated ice-volume loss and the estimated precipitation from measurements are in good agreement with runoff measurements. An energybalance model (Snow Distributed Energy balance Model, SnowDEM) was run, with and without a gravitational mass transport and deposition (MTD) routine, for the period 2005/ 06. The model run, which does not include mass transport, overestimates the water availability in the basin throughout the year by about $40 \%$ due to overestimated snow and ice melt. However, the model run in which SnowDEM was coupled with the MTD produced a result closer to the measured runoff. This result leads us to conclude that the distribution of snow is not only important for the correct shape of the hydrograph and the water availability throughout the season, but also for the correct estimation of the runoff and the total water availability.

\section{METHODS}

\section{The field area}

Haut Glacier d'Arolla is a small north-facing temperate valley glacier located in southwest Switzerland on the main Alpine divide. It has been the subject of ongoing research in glacier mass and energy balance, hydrology, geochemistry and ice dynamics since the early 1990 s (see, e.g., Sharp and others, 1993; Arnold and others, 1996; Hubbard and others, 1998; Brock and others, 2000; Willis and others, 2002; Strasser and others, 2004; Arnold, 2005; Pellicciotti and others, 2005). The catchment area is approximately $13 \mathrm{~km}^{2}$, with a glaciated area of about $5.3 \mathrm{~km}^{2}$ and an elevation range $2500-$ 3800 ma.s.l. (Fig. 1). Haut Glacier d'Arolla, the largest glacier in the area, is $4.4 \mathrm{~km}^{2}$ in area and about $4 \mathrm{~km}$ long. It has been retreating since the second half of the 20th century (Oerlemans and others, 1998). Over the last decade, the equilibrium-line altitude has been well above $2800 \mathrm{~m}$ a.s.l. (Oerlemans and others, 1998), leading to a strong negative mass balance, with about $2.5-3 \mathrm{~m} \mathrm{a}^{-1}$ of surface ice ablation across the lower tongue and more than $100 \mathrm{~m}$ of retreat since 1989 (Hubbard and others, 1998). These values have increased during the last 6 years of our measurements. 


\section{Meteorological and glaciological measurements}

The meteorological measurements in the catchment are made at one permanent automatic weather station (AWS) (T1) in the proglacial area at 2500 ma.s.l., approximately $1 \mathrm{~km}$ distance from the glacier snout, and one permanent AWS (T2) in the non-glaciated part of the upper basin at $3000 \mathrm{~m}$ a.s.I., approximately $0.5 \mathrm{~km}$ from the glacier margin. Both of these stations are outside the glacier boundary layer. The lower station (T1) is influenced by katabatic winds and therefore records colder temperatures than it would in the absence of a glacier. The upper station (T2) records higher than expected temperatures, being located at a spot in a topographic bowl that warms up more than the rest of the catchment. Both stations measure shortwave incoming and outgoing radiation, longwave incoming and outgoing radiation, air temperature, relative humidity, wind speed and direction and precipitation. Snow height is only measured at T2 with an ultrasonic depth gauge. Another station (AWS glacier) is located on the glacier at about $2800 \mathrm{~m}$ a.s.l., and is used for validation of the model. Figure 1 shows the location of the automatic weather stations and ablation/accumulation stakes. AWS glacier is equipped similarly to $\mathrm{T} 1$ and $\mathrm{T} 2$, but lacks the precipitation gauge.

Hourly discharge has been recorded for more than 30 years at a location about $1 \mathrm{~km}$ from the present glacier snout $(100 \mathrm{~m}$ from T1) by the hydroelectric company Grande Dixence, using a pressure transducer in an artificial channel of known dimensions. The accuracy is given as $10 \%$.

Direct measurements of snow-depth distribution over the glacier were carried out in May 2006. These surveys also included measurements of snow density in snow pits. The snow-depth distribution was measured with a graduated metal pole. The snow density was measured by snow sampling in a snow pit with a small cylinder, which was weighted using a spring balance. A set of 16 ablation/ accumulation stakes has been monitored continuously since May 2005.

Two digital elevation models (DEMs) used for this study were derived from aerial photographs acquired in September 1999 and 2005 by the Glacier and Permafrost Working Group of the Laboratory of Hydraulics, Hydrology and Glaciology at ETH Zürich, using digital photogrammetry. The horizontal resolutions of the DEMs were $10 \mathrm{~m}$ and $25 \mathrm{~m}$, respectively. The absolute accuracy in the horizontal as well as in the vertical direction was $0.6-0.7 \mathrm{~m}$. The elevation changes on the glaciated area in the catchment have been estimated from the difference between these two DEMs with an accuracy of about $\pm 1 \mathrm{~m}$. Another DEM was generated in November 2006 using airborne laser scanning with a higher resolution (Vallet, 2002) but has been gridded to a resolution of $10 \mathrm{~m}$ to match the existing DEMs.

\section{Mass-balance modeling}

We use the energy-balance model SnowDEM (Corripio, 2002), coupled with a gravitational MTD routine (Gruber, 2007), to model the mass balance. Mass transport caused by wind distribution is not included in the present version of the model. SnowDEM is a distributed, multilayered snow energy-balance model that takes full account of topographic influences and simulates the following fluxes:

1. incoming and outgoing shortwave radiation (direct, diffuse and reflected);

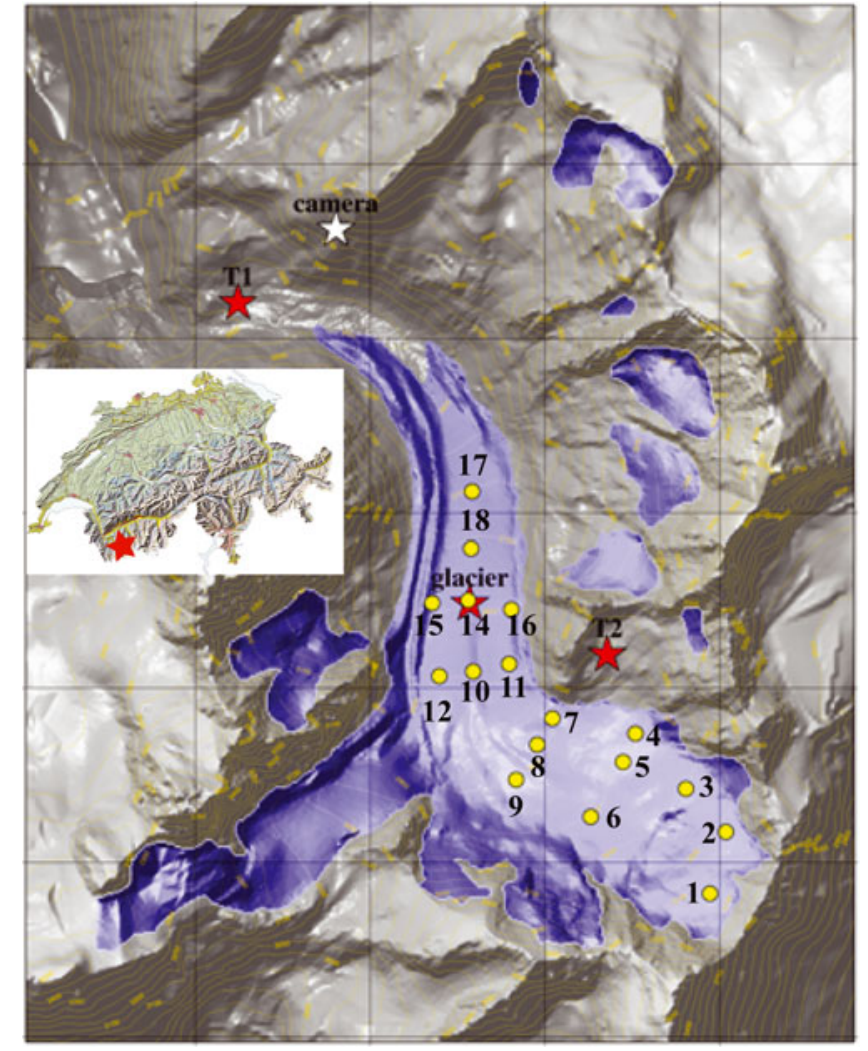

Fig. 1. Digital map of the Haut Glacier d'Arolla basin. Blue indicates the glaciated area $\left(5.3 \mathrm{~km}^{2}\right)$, red stars represent the locations of three automatic weather stations, white star is the location of an automatic camera and yellow circles depict the locations of accumulation/ablation stakes. The inset shows a map of Switzerland with the location of Haut Glacier d'Arolla.

2. incoming and outgoing longwave radiation (atmospheric thermal radiation and emitted radiation from surrounding slopes);

3. snow surface and subsurface temperature; and

4. latent and sensible turbulent heat interchange with the atmosphere.

The model is a slight modification of that described in Corripio (2002), which can be summarized in the following equation expressing the net energy flux at the surface, $Q$ :

$$
\mathrm{IG}(1-\alpha)+L \downarrow+L \uparrow+H+L_{\mathrm{v}} E+Q_{\mathrm{s}}+Q_{\mathrm{M}}=Q,
$$

where IG is global shortwave radiation, $\alpha$ is albedo, $L \downarrow$ is downward flux of longwave radiation, $L \uparrow$ is upward flux of longwave radiation, $H$ and $L_{v} E$ are sensible and latent heat fluxes, $Q_{\mathrm{s}}$ is internal heat flux within the snowpack and $Q_{M}$ is available heat for melting.

Coupled with SnowDEM is a mass-conserving algorithm to parameterize gravitational MTD using DEMs (Gruber, 2007). In this model, it is assumed that the potential flow from one cell to its neighbor is exclusively dependent upon topography. Only the elevation difference between cells (i.e. potential energy) is used in the flow propagation scheme, and kinetic energy is entirely neglected.

The model is run for the period Sepember 2005-October 2006, corresponding to the date of the DEM generation, so that it can be compared with ice volume loss which is estimated using the difference in elevation. The first model run (MR1) was completed without the MTD routine. A second 


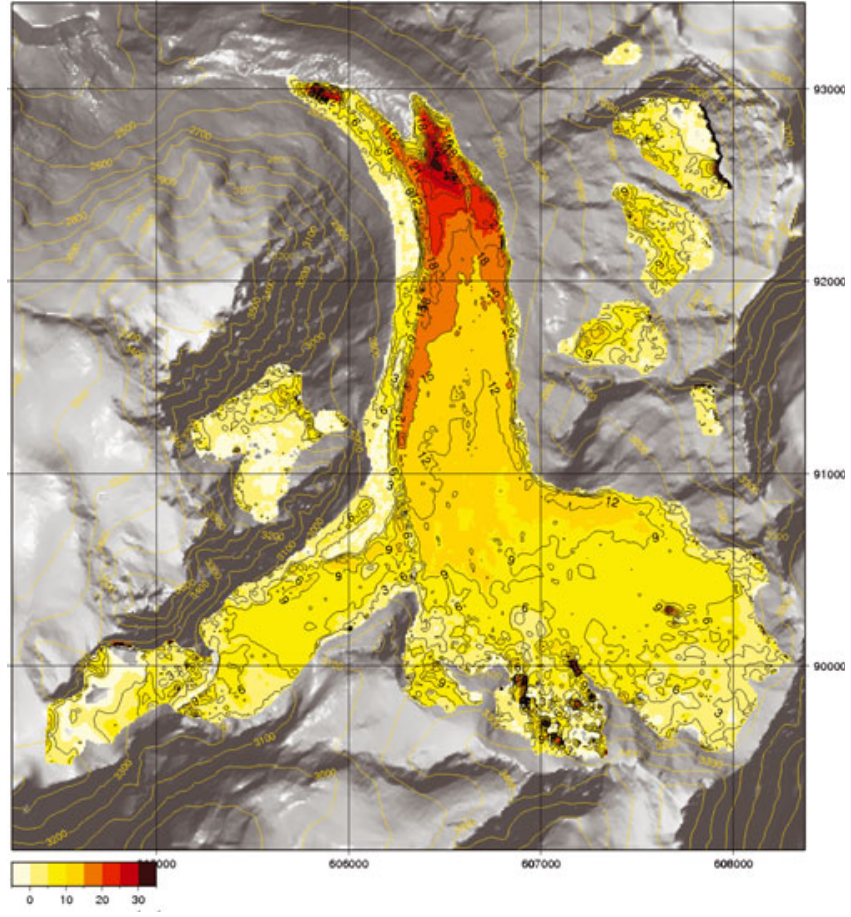

Fig. 2. Difference $(m)$ in elevation over the period 1999-2005 in the glaciated area of the Haut Glacier d'Arolla catchment area. The accuracy is about $1 \mathrm{~m}$. Average ice loss over the glaciated area is $7.5 \mathrm{~m}$. The background is a shaded image of the 1999 DEM.

model run (MR2) was coupled with MTD and the routine was run every time-step at which precipitation was not zero. The model was run using input data from T1, chosen over T2 as it better represents the climate of a glaciated catchment. The lapse rates used for the model were estimated from US National Centers for Environmental Prediction (NCEP) re-analysis data provided by the US National Oceanic and Atmospheric Administration (NOAA) office of Oceanic and Atmospheric Research (OAR) Earth Systems Research Laboratory (ESRL) Physical Sciences Division (PSD), Boulder, Colorado (http://www.cdc.noaa.gov/; Kalnay and others, 1996). A precipitation gradient of $0.8 \mathrm{~m} \mathrm{~km}^{-1} \mathrm{a}^{-1}$ is used.

\section{RESULTS}

\section{Contribution from ice-volume loss to runoff: 1999-2005}

The estimated loss of ice volume, derived from elevation changes in the DEMs, is approximately $(40 \pm 5) \times 10^{6} \mathrm{~m}^{3}$ for the 6 years from 1999 to 2005 (Fig. 2). Maximum icethickness loss of $35 \mathrm{~m}$ is at the decaying tongue. This part of the tongue is downwasting melting ice, which is decoupled from the dynamical part of the glacier. The specific net balance for this period is $-7.5 \pm 1 \mathrm{~m}$ (of ice). This results in an average annual loss of ice volume of $6.6 \times 10^{6} \mathrm{~m}^{3}$ and an average annual specific net balance of $-1.25 \mathrm{~m}$ (Table 1 ).

The measured runoff for the same period is $150 \times 10^{6} \mathrm{~m}^{3}$ of water, whereas water generation from ice melt, derived from the volume loss, is $(36 \pm 5) \times 10^{6} \mathrm{~m}^{3}$. Thus, the ice melt contributes about $25 \%$ to the annual runoff in the catchment area. The other $75 \%$ is either from snowmelt or from rain. This is consistent with our precipitation measurements, which result in a total measured precipitation of $92 \times 10^{6} \mathrm{~m}^{3}$ of generated water inside the catchment. It should be noted
Table 1. Annual average values of components contributing to runoff for the periods 1999-2005 and 2005-06

\begin{tabular}{lcc}
\hline & 1999-2005 & 2005-06 \\
\hline Runoff $\left(\times 10^{6} \mathrm{~m}^{3}\right)$ & 25 & 30 \\
Ice melt $\left(\times 10^{6} \mathrm{~m}^{3}\right)$ & 6 & 10 \\
Precipitation $\left(\times 10^{6} \mathrm{~m}^{3}\right)$ & 15 & 16 \\
Specific net balance $(\mathrm{m}$ ice $)$ & -1.25 & -2.0 \\
\hline
\end{tabular}

that the measured precipitation can be underestimated by up to $50 \%$ due to undercatching in the precipitation gauge during snowfall because of wind. These estimations correspond to $25 \times 10^{6} \mathrm{~m}^{3}$ of annual runoff, $6 \times 10^{6} \mathrm{~m}^{3}$ of annual water generation due to ice melt and $15 \times 10^{6} \mathrm{~m}^{3}$ of annual water generation due to precipitation (Table 1 ).

\section{Ice velocities}

In order to be able to fully interpret the spacial variation depicted in Figure 2, ice dynamics should be considered. We do not address this topic here, but measurements show that the ice flow is rather slow. Measurements of ice velocities in August 2005 (personal communication from D.W.F. Mair) show highest velocities in the upper part of the glacier, with a maximum of $11 \mathrm{ma}^{-1}$. The annual velocities are slightly smaller, with a maximum of $10 \mathrm{~m} \mathrm{a}^{-1}$.

\section{Contribution from ice-volume loss to runoff: 2005-06}

The estimated loss of ice volume, derived from elevation changes in DEMs from 2005 and 2006, is approximately $11 \times 10^{6} \mathrm{~m}^{3}$, with very similar ice ablation distribution in the period 1999-2005 (Fig. 2). The specific net balance is $-2 \mathrm{~m}$ (of ice).

The measured runoff for the period $2005-06$ is $30 \times 10^{6} \mathrm{~m}^{3}$, the water generation from ice melt about $10 \times 10^{6} \mathrm{~m}^{3}$ and the estimated precipitation $16 \times 10^{6} \mathrm{~m}^{3}$ (Table 1 ). For comparison, the measured runoff in the remarkably hot year 2003 was also $30 \times 10^{6} \mathrm{~m}^{3}$, although this year had a much shorter melt season than 2006 .

\section{Model results from SnowDEM: 2005-06}

SnowDEM was run for the period September 2005-October 2006 using input data from station T1. In the first model run (MR1), MTD was not coupled to SnowDEM. The algorithm was included in the second model run (MR2), however, being executed each time-step where precipitation was greater than zero.

MR1 overestimates the measured runoff by about $40 \%$, while MR2 overestimates the runoff by $<10 \%$ (Table 2 ). The difference between MR1 and MR2 is mainly due to runoff generation from snowmelt. The snow-covered area in MR1 is much larger than in MR2, because steep areas have less or no snow in MR2. The difference in ice melt is caused by longer-lasting snow in regions where avalanches occur, and ice is therefore exposed later. The resulting specific net balance for MR1 and MR2 is $-2.6 \mathrm{ma}^{-1}$ and $-2.3 \mathrm{ma}^{-1}$, respectively.

The model results from MR1 are mainly altitude-dependent, while the results from MR2 vary for a given altitude (depending on distance from avalanching slopes). Table 3 shows 
Table 2. Model results for MR1 and MR2, showing the different components of the contribution to runoff in the 2005-06 season

\begin{tabular}{lcc}
\hline & MR1 & MR2 \\
\hline Runoff $\left(\times 10^{6} \mathrm{~m}^{3}\right)$ & 41 & 32 \\
Ice melt $\left(\times 10^{6} \mathrm{~m}^{3}\right)$ & 13 & 11 \\
Snowmelt $\left(\times 10^{6} \mathrm{~m}^{3}\right)$ & 22 & 15 \\
Rain $\left(\times 10^{6} \mathrm{~m}^{3}\right)$ & 6 & 6 \\
Specific net balance $(\mathrm{m}$ ice) & -2.6 & -2.0 \\
\hline
\end{tabular}

the comparison between measured and modeled snow water equivalent (SWE) at day 144 for MR1 and MR2. In general, modeled SWE is underestimated in the upper part of the glacier and overestimated in the lower part. Figure 3 shows the ablation/accumulation measurements from the AWS glacier ultrasonic depth gauge against model results from MR1 at the same location. The model's predictions are accurate for ice melt up until day 210, when snowfall occurs, after which the predictions are less accurate. It is not clear if this inaccuracy is due only to the overestimated albedo after summer snowfall (Fig. 3, dashed line for modeled albedo) or to neglected snow settling in the model.

\section{DISCUSSION AND CONCLUSION}

Ice-volume loss has been estimated using DEMs from different time periods. The maximum ice-thickness loss during a 6 year period (1999-2005) was $7.5 \mathrm{~m}$ at the decaying tongue. The specific net balance over the whole glaciated area is $-1.25 \mathrm{~m} \mathrm{a}^{-1}$ between 1999 and 2005, and $-2 \mathrm{~m} \mathrm{a}^{-1}$ for the year 2005-06. The estimated ice-volume loss and the estimated precipitation from measurements are in good agreement with runoff measurements.

An energy-balance model including a gravitational MTD routine was run for the period 2005-06. MTD was not included in the first model run (MR1), while it was fully coupled

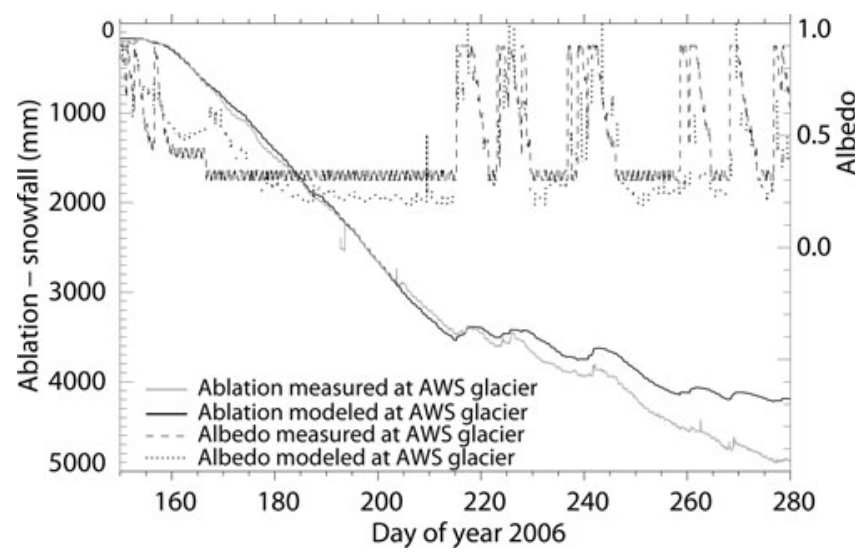

Fig. 3. Measured ablation (gray line) using an ultrasonic depth gauge against modeled ablation (black line) from the model run including the MTD routine. The dotted line is measured albedo; the dashed line is modeled albedo. No snow settling is included in the model, which makes results after snowfall events difficult to interpret.

in the second model run (MR2). MR1 overestimates the measured runoff by about $40 \%$, while MR2 overestimates the runoff by $<10 \%$. The contribution of runoff from snowmelt is the main discrepancy between MR1 and MR2. The snowcovered surface becomes smaller when snow is removed from steep slopes, which results in less snowmelt. However, water generation from precipitation is overestimated in both models. One of the reasons for this could be that our model does not include a snowdrift routine. Mernild and others (2006) show that approximately $12 \%$ of the precipitation can be returned to the atmosphere by sublimation of drifting snow. However, including the MTD routine in MR2 remarkably improves the results (both runoff and ice melt). The avalanching routine transports snow from steep walls down onto the glacier, keeps the glacier snow-covered for longer and therefore leads to less ice melt. If ice is exposed earlier, the melt season for ice is longer which enhances ice melt due to the lower albedo of ice.

Table 3. Model results for MR1 and MR2 for day 144, compared with measured snow depths on the same day

\begin{tabular}{|c|c|c|c|c|c|c|}
\hline $\begin{array}{c}\text { Stake No. (altitude) } \\
\text { (m a.s.l.) }\end{array}$ & $\begin{array}{l}\text { SWE measured } \\
\text { mm }\end{array}$ & $\begin{array}{l}\text { SWE modeled (MR1) } \\
\text { mm }\end{array}$ & $\begin{array}{l}\text { SWE modeled (MR2) } \\
\text { mm }\end{array}$ & $\begin{array}{c}\text { Measured - MR1 } \\
\text { mm }\end{array}$ & $\begin{array}{c}\text { Measured - MR2 } \\
\mathrm{mm}\end{array}$ & $\begin{array}{c}\text { MR1 - MR2 } \\
\mathrm{mm}\end{array}$ \\
\hline $1(3135)$ & $>1000$ & 970 & 1170 & + & $?$ & -200 \\
\hline $2(3085)$ & $>1000$ & 940 & 660 & + & + & 180 \\
\hline $3(3050)$ & 1000 & 890 & 910 & 110 & 90 & -20 \\
\hline $4(2956)$ & 850 & 850 & 1120 & 0 & -270 & -270 \\
\hline $6(2958)$ & 1000 & 850 & 980 & 150 & 20 & -130 \\
\hline 7 (2902) & 850 & 820 & 810 & 30 & 40 & 10 \\
\hline $8(2900)$ & 850 & 820 & 810 & 30 & 40 & 10 \\
\hline $9(2902)$ & 900 & 820 & 940 & 80 & -40 & -120 \\
\hline $10(2838)$ & 750 & 780 & 810 & -30 & -60 & -30 \\
\hline $11(2836)$ & 800 & 780 & 790 & 20 & 10 & -10 \\
\hline $12(2854)$ & 750 & 780 & 770 & -30 & -20 & 10 \\
\hline $15(2792)$ & 550 & 730 & 720 & -180 & -170 & 10 \\
\hline $16(2774)$ & 650 & 740 & 730 & -90 & -80 & 10 \\
\hline $17(2700)$ & 750 & 660 & 650 & 90 & 100 & 10 \\
\hline $18(2752)$ & 600 & 710 & 690 & -110 & -90 & 20 \\
\hline
\end{tabular}


The difference in modeled and measured mass balance (estimated from DEMs) is caused mainly by differences in snow distribution, which indirectly affect the energy balance by influencing the albedo, reflected shortwave radiation from surrounding slopes and the longwave outgoing radiation. These effects are very important and require further consideration. Figure 3 shows that ice ablation at the location of AWS glacier is in good agreement with measurements, while the time after summer snowfall is represented rather poorly. This is due either to an overestimation of albedo in the model or to the neglected settling, which is represented in the measurement. We have not included snow settling in the model and therefore cannot quantify this effect. Table 3 shows that modeled SWE is generally underestimated by a greater amount in the upper part of the glacier than in the lower part. A possible reason for this might be neglected snow redistribution by wind, and neglected topographical influences on precipitation distribution. The results also show that some avalanches are well represented with MTD (e.g. stakes 6, 9, 11 and 15) while others are overestimated (stakes 4 and 10). Because MTD is only slope-dependent, it neglects snow stratigraphy which is crucial for a correct representation of avalanches. It therefore cannot be used for predicting single avalanche events. However, our results show that it is a very valuable tool for hydrological and glacier mass-balance estimations.

Our results lead to the conclusion that the distribution of snow is important not only for the timing of streamflow throughout the year, but also for the total amount of water available from a basin (Table 2). The snow distribution has the largest effect on snowmelt, depending on how much snowcovered area is exposed. Furthermore, if the snow is not distributed correctly within the basin, the ice cover will become exposed too early or too late in the season, leading to incorrect estimates of ice melt. It is therefore very important to include other processes in mass-balance models, which can improve the snow distribution inside a catchment. Some of these processes are distribution of snow due to wind, sublimation of drifting snow and the precipitation distribution due to topographical obstacles in steep terrain.

\section{ACKNOWLEDGEMENTS}

We are very grateful to T. Blunschi, H. Bösch, M. Funk, M.G. Haas, P. Jenni, T. Keller, F. Pellicciotti, P. Perona, S. Rimkus, K. Schroff, C. Senn, R. Weber and T. Wyder. Many thanks to S. Gruber for providing help with MTD. Grande Dixence SA provided the runoff measurements. We also thank M.B. Dyurgerov and S.A. Sokratov for valuable comments and suggestions. The project is carried out under Swiss National Science Foundation grant No. 200021105586.

\section{REFERENCES}

Arnell, N.W. 1999. The effect of climate change on hydrological regimes in Europe: a continental perspective. Global Environ. Res., 9(1), 5-23.

Arnold, N. 2005. Investigating the sensitivity of glacier massbalance/elevation profiles to changing meteorological conditions: model experiments for Haut Glacier D'Arolla, Valais, Switzerland. Arct. Antarct. Alp. Res., 37(2), 139-145.

Arnold, N.S., I.C. Willis, M.J. Sharp, K.S. Richards and W.J. Lawson. 1996. A distributed surface energy-balance model for a small valley glacier. I. Development and testing for Haut Glacier d'Arolla, Valais, Switzerland. J. Glaciol., 42(140), 77-89.

Brock, B.W., I.C. Willis, M.J. Sharp and N.S. Arnold. 2000. Modelling seasonal and spatial variations in the surface energy balance of Haut Glacier d'Arolla, Switzerland. Ann. Glaciol., 31, $53-62$.

Corripio, J.G. 2002. Modelling the energy balance of high altitude basins in the Central Andes. (PhD thesis, University of Edinburgh.)

Gruber, S. 2007. A mass-conserving fast algorithm to parameterize gravitational transport and deposition using digital elevation models. Water Resour. Res., 42(W06), W06412. (10.1029/2006WR004868.)

Hubbard, A., H. Blatter, P. Nienow, D. Mair and B. Hubbard. 1998. Comparison of a three-dimensional model for glacier flow with field data from Haut Glacier d'Arolla, Switzerland. J. Glaciol., 44(147), 368-378.

Kalnay, E. and 21 others. 1996. The NCEP/NCAR 40-year reanalysis project. Bull. Am. Meteorol. Soc., 77(3), 437-471.

Mernild, S.H., G.E. Liston, B. Hasholt and N.T. Knudsen. 2006. Snow distribution and melt modeling for Mittivakkat Glacier, Ammassalik Island, Southeast Greenland. J. Hydromet., 7(4), 808-824.

Oerlemans, J. and 10 others. 1998. Modelling the response of glaciers to climate warming. Climate Dyn., 14(4), 267-274.

Pellicciotti, F., B.W. Brock, U. Strasser, P. Burlando, M. Funk and J.G. Corripio. 2005. An enhanced temperature-index glacier melt model including shortwave radiation balance: development and testing for Haut Glacier d'Arolla, Switzerland. J. Glaciol., 51(175), 573-587.

Sharp, M.J. and 6 others. 1993. Geometry, bed topography and drainage system structure of the Haut Glacier d'Arolla, Switzerland. Earth Surf. Process. Landf., 18(6), 557-571.

Strasser, U., J. Corripio, F. Pellicciotti, P. Burlando, B. Brock and M. Funk. 2004. Spatial and temporal variability of meteorological variables at Haut Glacier d'Arolla (Switzerland) during the ablation season 2001: measurements and simulations. J. Geophys. Res., 109(D3), D03103 (10.1029/2003JD003973.).

Vallet, J. 2002. Saisie de la couverture neigeuse des sites avalancheux par des techniques aéroportés. (PhD thesis, Ecole Polytechnique Fédérale de Lausanne.)

Willis, I.C., N.S. Arnold and B.W. Brock. 2002. Effect of snowpack removal on energy balance, melt and runoff in a small supraglacial catchment. Hydrol. Process., 16(14), 2721-2749. 